\title{
Anemia in COPD: A Systematic Review of the Prevalence, Quality of Life, and Mortality
}

\author{
Abebaw Mengistu Yohannes PhD MSc and William Baldwin Ershler MD
}

\author{
Introduction \\ Literature Search Strategy and Selection Criteria \\ Study Characteristics \\ Prevalence of Anemia in COPD \\ Pathophysiology of Anemia in COPD \\ Morbidity and Mortality \\ Quality of Life \\ Summary and Comments
}

\begin{abstract}
Anemia is common in patients with chronic diseases. However, little is known regarding the prevalence of comorbid anemia and its impact on quality of life, healthcare utilization, and mortality in patients with COPD. We conducted a systematic review and synthesis of the literature (1966 to March 2010). The prevalence of comorbid anemia in patients with COPD ranges from $7.5 \%$ to $34 \%$, depending upon the populations selected and diagnostic tools employed to determine the level of hemoglobin. Comorbid anemia in patients with COPD was associated with greater healthcare resource utilization, impaired quality of life, older age, and male gender. Moreover, anemia in patients with COPD is an independent prognostic predictor of premature mortality and a greater likelihood of hospitalization. The true prevalence of anemia in patients with COPD is unknown. There is a lack of consensus agreement regarding this hematological abnormality's true frequency. Based on the findings from the existing literature, more work is necessary to establish the true prevalence of anemia in COPD. Robust and prospective clinical studies are needed to improve the management of COPD patients with comorbid anemia. Key words: anemia; COPD; quality life; morbidity; mortality; healthcare utilization. [Respir Care 2011;56(5):644-652. (c) 2011 Daedalus Enterprises]
\end{abstract}

\section{Introduction}

COPD is a disease characterized by severe incurable air-flow limitation and reduced functional capacity, associated with multiple comorbidities and markers of systemic inflammation. ${ }^{1}$ The disease is a major cause of mor-

\footnotetext{
Abebaw Mengistu Yohannes PhD MSc is affiliated with the Department of Health Professions, Manchester Metropolitan University, Manchester, United Kingdom. William Baldwin Ershler MD is affiliated with the National Institute on Aging, National Institutes of Health, and with Harbor Hospital, Baltimore, Maryland.
}

The authors have disclosed no conflicts of interest. bidity and mortality in old age, and accounts for the greatest proportion of mortality of all respiratory diseases. ${ }^{2,3}$ Currently, COPD is the third leading cause of death in Europe ${ }^{4,5}$ and is ranked as the fourth leading cause of death in the United States. ${ }^{6}$ Studies have shown an exponential rise of healthcare utilization and associated financial bur-

\footnotetext{
Correspondence: Abebaw Mengistu Yohannes PhD MSc, Department of Health Professions, Manchester Metropolitan University, Elizabeth Gaskell Campus, Hathersage Road, Manchester, United Kingdom M13 0JA. E-mail: a.yohannes@mmu.ac.uk.
}

DOI: $10.4187 /$ respcare.01002 
den, along with an increased rate of mortality among COPD patients, all of which are projected to increase in the next two decades. . $^{7}$

In the United States in $2010,{ }^{8}$ the total cost of COPD management was estimated $\$ 49.9$ billion. Of this, the direct medical cost to COPD was $\$ 29.5$ billion and the indirect costs (eg, earning lost because of absence from work, morbidity and mortality related costs) was $\$ 20.4$ billon. This, however, may represent merely the tip of the iceberg, as the full extent of the disease's financial burden is unknown. Some of the common comorbidities that contribute to the increased risk associated with morbidity and mortality in patients with COPD include cardiovascular disease, hypertension, diabetes mellitus, hypercholesterolemia, osteoporosis, and anemia. ${ }^{7,9,10,11}$ It may, therefore, not be surprising to find that one third to fifty percent of deaths in COPD patients are attributable to factors (eg, comorbidities) other than COPD. ${ }^{3,10}$ Moreover, mood disorders (anxiety and depression) are common in patients with COPD and associate as risk factors for premature death. ${ }^{12}$ The exact cause of these comorbidities is currently unknown; however, recent research indicates that systemic inflammation is associated with their development.7,10,11,13

The World Health Organization defines anemia in the general population as hemoglobin concentration $<13.0 \mathrm{~g} / \mathrm{dL}$ in men and $<12.0 \mathrm{~g} / \mathrm{dL}$ in women, ${ }^{14}$ a definition appropriate for older persons. ${ }^{15}$ In patients with COPD there is no specific hemoglobin concentration level as a cutoff score to determine which is clinically meaningful. Therefore, clinical surveys and studies utilize different anemia definitions when defining anemic and nonanemic COPD patients. This has led to a lack of consensus to determine the prevalence of anemia in patients with COPD. Findings from recent studies that investigated the prevalence of anemia indicate varying results. A community survey among COPD patients found the prevalence of anemia (hemoglobin $<13 \mathrm{~g} / \mathrm{dL}$ ) to be $7.5 \% .{ }^{16}$ Two studies $^{17,18}$ utilizing the International Classification of Diseases (ICD-9 or ICD-10) codes for hospital discharge diagnoses found $21 \%$ and $23 \%$ of COPD patients had anemia. Cote and John ${ }^{19,20}$ used the World Health Organization's criteria for diagnosis of anemia ${ }^{14}$ (hemoglobin $<13 \mathrm{~g} / \mathrm{dL}$ for men and $<12 \mathrm{~g} / \mathrm{dL}$ for women), and found it to be present in $13 \%$ and $17 \%$ in their study sample of COPD patients. Thus, the prevalence of coexisting anemia in patients with COPD is highly variable and depends on the severity of the lung disease, the presence of other comorbidities, and other factors such as socioeconomic status and race.

Fatigue and dyspnea are the major symptoms of anemia, and these can be related to reduced oxygen carrying capacity of blood. ${ }^{16,19}$ Furthermore, this symptom complex in patients with COPD will inevitably contribute the morbidity and mortality associated with impaired quality of life and reduced exercise capacity. ${ }^{16,18}$ Nonetheless, the important association of anemia and COPD has been inadequately studied. This review intends to update and synthesize the available data on the prevalence of anemia and its physiological consequences for patients with COPD, with particular focus on quality of life, healthcare utilization, morbidity, and mortality.

\section{Literature Search Strategy and Selection Criteria}

An extensive literature search was conducted to identify relevant published articles evaluating COPD and anemia as a single associated comorbidity. The electronic databases explored included: PubMed, CINAHL plus, MEDLINE (CSA), AMED, and the Cochrane library from 1966 through to March 2010. The search was performed using the following subject terms and key words: COPD, COPD, an(a)emia, h(a)ematocrit, erythropoietin, iron deficiency, red blood cells, and h(a)emoglobin level. Studies were included that set limits for human studies attainable in English. An iterative procedure was used to certify that all pertinent articles were obtained. A supplementary hand search of bibliographic references of extracted articles and existing reviews was also conducted to identify potential studies not ascertained in the electronic database searches.

A single member of our team screened article titles from the preliminary search and acquired the abstracts from articles considered potentially relevant. Each abstract was independently evaluated by the same research member, who then retrieved the full text. This procedure was followed by a second reviewer for independent confirmation. An article was considered relevant for full text retrieval if it met the following inclusion criteria:

- Studies that reported the prevalence of anemia

- Studies that explored the relationship between anemia and COPD, in either community, in-patient, or out-patient settings

- Randomized or nonrandomized study design; either prospective or retrospective

\section{Study Characteristics}

A total of 693 article titles were ascertained as potentially relevant, based on the keyword/search terms, along with the hand search of bibliographic references. Of these, 114 were classified as potentially appropriate. After the initial screening, 105 were excluded. Nine full-text articles were determined appropriate for this analysis (Fig. 1) but only 7 fully met the inclusion criteria. Details of the findings from these 7 studies are presented in Table 1. The inclusion and exclusion criteria for the selected articles are shown in Table 2. 


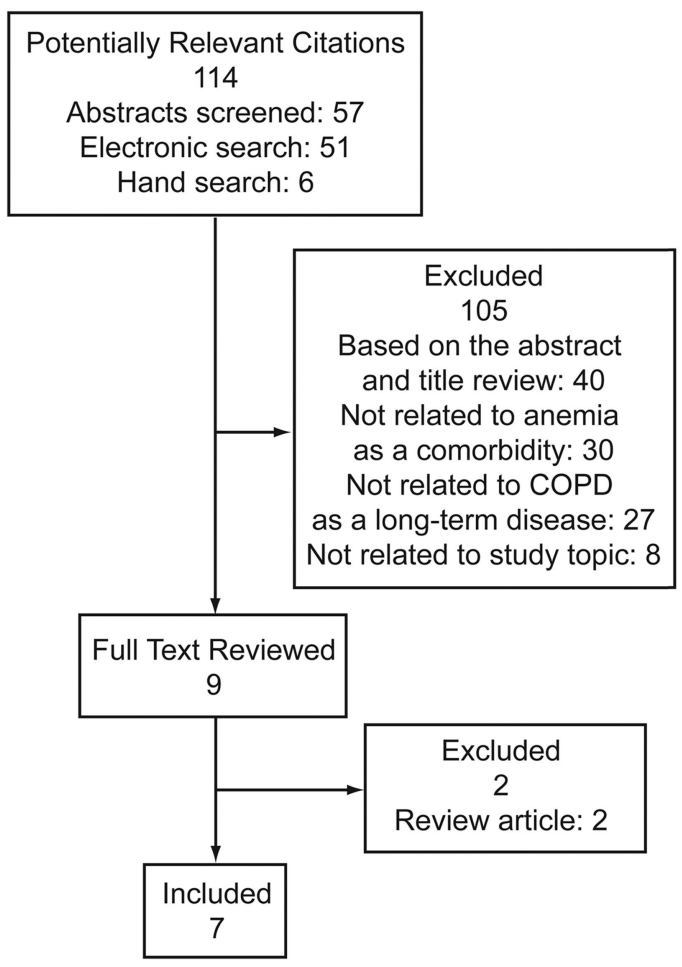

Fig. 1. Flowchart of literature search.

\section{Prevalence of Anemia in COPD}

John and colleagues ${ }^{18}$ estimated the prevalence of anemia at $23.1 \%$. However, they noted that neither age nor spirometric measures differed between the anemic and nonanemic COPD patients. Those with notably lower hemoglobin levels, however, had evidence for a greater level of systemic inflammation as indicated by increased levels of both interleukin 6 (IL-6) and C-reactive protein. ${ }^{20}$ From the Medicare claims data, Halpern et al ${ }^{17}$ identified anemia in $21 \%$ of patients with COPD. By multivariable analysis they were able to account for prior healthcare utilization and other factors associated with the severity of COPD. It was shown that Medicare spent $\$ 1,466$ per patient per year among COPD patients with anemia, versus $\$ 649$ per person per year in non-anemic COPD patients $(P<.001)$. Resource utilization rates and payments among the COPD patients with anemia were higher in every resource category. This included in-patient hospital stay and stay in intensive care, purchasing durable medical equipment, home health assistance, and provision of skilled nursing facilities. A recent report by Shorr et al, ${ }^{21}$ using ICD-9 diagnosis criteria, reported the prevalence of comorbid anemia in patients with COPD to be $33 \%$. By their analysis, annual costs for COPD patients with anemia were $\$ 17,240$, compared to $\$ 6,492$ for COPD patients without anemia $(P<.001)$. Anemic COPD patients had greater comorbidity and were more likely to be male, older, and to utilize healthcare resources to a greater extent than nonanemic patients.

In contrast to the findings of John and colleagues, ${ }^{18}$ Chambellan et al, ${ }^{9}$ in patients with severe oxygen-dependent COPD, established that anemia (defined by hematocrit $<39 \%$ in men and $<36 \%$ in women) was present in $13 \%$ of the men and $8 \%$ of the women. Anemia was also correlated with age and disease severity. The results also supported the clinical impression that hematocrit is an independent predictor of survival, hospital admission, and hospital stay. ${ }^{9}$ That retrospective analysis had methodological constraints. For example, hematocrit was only measured once during the study, at the initiation of long-term oxygen therapy. In addition, the stability of the oxygen prescription and smoking status was not established, and both of those variables may influence the likelihood of anemia. Also there was no identification of comorbidities, which may be responsible for anemia in COPD patients. Despite these methodological limitations, the use of a large national database (maintained for over 25 years by the Association Nationale pour le Treatment à Domicile de I'Insuffisance Respiratoire), substantially enhances the overall reliability of these observations.

Cote and colleagues ${ }^{19}$ retrospectively analyzed data that was prospectively collected at one of the sites (Bay Pines Veterans Affair Medical Center, Bay Pines, Florida) of the multicenter BODE (body-mass index, air-flow obstruction, dyspnea, and exercise capacity index) study. The prevalence of anemia in COPD patients was estimated to be $17 \%$. However, the confinement of the study sample solely to the Veterans Affair Medical Center may diminish the generalizability of the findings.

John and co-workers, ${ }^{18}$ with a sample of 7,337 patients, compared the prevalence of anemia between hospital-admitted COPD and other chronic diseases (asthma, chronic heart failure, chronic renal insufficiency, and cancer). They reported that, in a sample of 312 COPD patients, $23 \%$ had anemia regardless of disease severity. The prevalence of anemia in COPD patients was comparable to that in patients with chronic heart failure (23\% of 189), higher than that in patients with asthma (10\% of 183), but lower than that in patients with cancer $(45 \%$ of 2,124$)$ or chronic renal failure (75\% of 234). These values were obtained from ICD-9/10 code of the discharge diagnoses and provide very little explanation of the potential causes of anemia, such as inflammation or disorders that affect bone marrow function. ${ }^{18}$

\section{Pathophysiology of Anemia in COPD}

Although the precise cause of anemia in COPD patients is unknown, there appears to be a relationship with certain pro-inflammatory markers (Fig. 2), which suggests that at 
Anemia in COPD: A Systematic Review

Table 1. Studies That Met the Inclusion Criteria, and Sociodemographic Characteristics of COPD Patients With Anemia

\begin{tabular}{|c|c|c|c|c|c|c|c|}
\hline $\begin{array}{l}\text { First } \\
\text { Author }\end{array}$ & Year & Country & Study Design & $\begin{array}{l}\text { Sample Size of } \\
\text { COPD Patients }\end{array}$ & $\begin{array}{l}\text { Anemia } \\
\text { Prevalence } \\
\text { no. }(\%)\end{array}$ & $\begin{array}{l}\text { COPD Diagnosis } \\
\text { Method }\end{array}$ & Hemoglobin Definition \\
\hline Shorr $^{21}$ & 2008 & United States & $\begin{array}{l}\text { Retrospective } \\
\text { cohort }\end{array}$ & 2,404 & $788(32.7)$ & ICD-9 & $\begin{array}{l}\text { World Health Organization } \\
\text { Male }<13 \mathrm{~g} / \mathrm{dL} \\
\text { Female }<12 \mathrm{~g} / \mathrm{dL}\end{array}$ \\
\hline Chambellan ${ }^{9}$ & 2005 & France & $\begin{array}{l}\text { Retrospective } \\
\text { Patients on long- } \\
\text { term oxygen } \\
\text { therapy } \\
\text { (patient } \\
\text { records) }\end{array}$ & 2,524 & $\begin{array}{l}264 \text { men }(12.6 \%) \\
\text { had hematocrit } \\
<39 \% \\
35 \text { women } \\
(8.2 \%) \text { had } \\
\text { hematocrit } \\
<36 \%\end{array}$ & $\begin{array}{c}\mathrm{FEV}_{1} / \mathrm{FVC}<70 \%, \\
\mathrm{FEV}^{1}<80 \% \\
\text { predicted, } \mathrm{P}_{\mathrm{aO}_{2}} \\
<55 \mathrm{~mm} \mathrm{Hg}, \\
\text { and hematocrit } \\
\text { documented }\end{array}$ & $\begin{array}{l}\text { Male hematocrit }<39 \% \\
\text { Female hematocrit }<36 \%\end{array}$ \\
\hline Cote $^{19}$ & 2007 & United States & $\begin{array}{l}\text { Hemoglobin data } \\
\text { collected } \\
\text { retrospectively } \\
\text { All other data } \\
\text { collected } \\
\text { prospectively }\end{array}$ & $\begin{array}{l}677 \text { eligible for } \\
\text { analysis }\end{array}$ & $116(17.1)$ & $\begin{array}{l}>20 \text { pack-years } \\
\text { smoking history and } \\
\mathrm{FEV}_{1} / \mathrm{FVC}<70 \%\end{array}$ & $\begin{array}{l}\text { Male }<13 \mathrm{~g} / \mathrm{dL} \\
\text { Female }<13 \mathrm{~g} / \mathrm{dL}\end{array}$ \\
\hline Krishnan $^{16}$ & 2006 & United States & Retrospective & $\begin{array}{l}495(18 \%) \text { had } \\
\text { complete data } \\
\text { for inclusion }\end{array}$ & $37(7.5)$ & $\begin{array}{l}\text { Spirometry calculated } \\
\text { FEV }_{1} \text { and FVC } \\
\text { prediction equations } \\
\text { Patients categorized per } \\
\text { the Global Initiative } \\
\text { for Chronic } \\
\text { Obstructive Lung } \\
\text { Disease stages }\end{array}$ & $\begin{array}{l}\text { World Health Organization } \\
\text { Male }<13 \mathrm{~g} / \mathrm{dL} \\
\text { Female }<12 \mathrm{~g} / \mathrm{dL}\end{array}$ \\
\hline Halpern $^{17}$ & 2006 & United States & $\begin{array}{l}\text { Retrospective } \\
\text { study }\end{array}$ & 132,424 & $27,932(21.1)$ & $\begin{array}{l}\text { Diagnosed by physician/ } \\
\text { supplier or out-patient } \\
\text { file }\end{array}$ & $\begin{array}{l}\text { ICD-9 specific to anemia, } \\
\text { or receipt of a } \\
\text { transfusion not } \\
\text { associated with other } \\
\text { causes (eg, blood loss } \\
\text { from surgery or trauma) }\end{array}$ \\
\hline $\mathrm{John}^{18}$ & 2006 & Germany & $\begin{array}{l}\text { Retrospective } \\
\text { study }\end{array}$ & 312 & $72(23.1)$ & $\begin{array}{l}\text { ICD-9 until year 2000, } \\
\text { then ICD-10 (J44.9 } \\
\text { COPD unspecified) } \\
\text { Severity subgrouping } \\
\text { per Global Initiative } \\
\text { for Chronic } \\
\text { Obstructive Lung } \\
\text { Disease }\end{array}$ & $\begin{array}{l}\text { Male }<13.5 \mathrm{~g} / \mathrm{dL} \\
\text { Female }<12 \mathrm{~g} / \mathrm{dL}\end{array}$ \\
\hline $\mathrm{John}^{20}$ & 2005 & Germany & $\begin{array}{l}\text { Prospective out- } \\
\text { patient }\end{array}$ & 101 & $13(13.1)$ & $\begin{array}{l}\text { Spirometry calculated } \\
\text { percent predicted } \\
\text { FEV }_{1} \text { and FVC }\end{array}$ & $\begin{array}{l}\text { Male }<13.5 \mathrm{~g} / \mathrm{dL} \\
\text { Female }<12 \mathrm{~g} / \mathrm{dL}\end{array}$ \\
\hline
\end{tabular}

least a component of the anemia is attributable to inflammation (ie, the anemia of chronic inflammation). ${ }^{22}$

Tassiopoulos and colleagues, ${ }^{23}$ in 2001 , were among the first to study anemia and its compensatory erythropoietic action in COPD patients. Their findings indicated an inverse correlation between the hemoglobin and erythropoietin concentrations, which suggests that in COPD patients low hemoglobin correlates with a compensatory erythropoietin response.
The causes of anemia in patients with COPD are probably multifactorial and include nutritional deficits, stress ulcer (especially those on steroids), and carboxyhemoglobin effects of cigarette smoking. A particularly important cause of anemia in these patients may relate to the chronic inflammatory nature of COPD. The anemia of chronic inflammation, which was previously termed the anemia of chronic disease, is one of the major causes of normocytic anemia in man. ${ }^{24}$ It is a hypoprolifertive anemia charac- 
Anemia in COPD: A Systematic Review

Table 2. Inclusion and Exclusion Criteria and Patients Enrolled

\begin{tabular}{|c|c|c|c|c|c|}
\hline $\begin{array}{l}\text { First } \\
\text { Author }\end{array}$ & Year & Country & Inclusion Criteria & Exclusion Criteria & $\begin{array}{l}\text { Patients Enrolled } \\
\text { no. }(\% *)\end{array}$ \\
\hline Shorr ${ }^{21}$ & 2008 & United States & $\begin{array}{l}\mathrm{FEV}_{1} / \mathrm{FVC}<70 \% \\
\mathrm{FEV}_{1}<80 \% \text { predicted }\end{array}$ & $\begin{array}{l}\text { Receiving cancer therapy } \\
\text { Hemoglobinopathies } \\
\text { Nutritional deficiencies }\end{array}$ & $\begin{array}{l}2,404 \\
\% \text { not specified }\end{array}$ \\
\hline Chambellan ${ }^{9}$ & 2005 & France & $\begin{array}{l}\mathrm{FEV}_{1} / \mathrm{FVC}<70 \% \\
\mathrm{FEV}_{1}<80 \% \text { predicted } \\
\mathrm{P}_{\mathrm{aO}_{2}}<55 \mathrm{~mm} \mathrm{Hg} \text { on } \\
\quad \text { room air } \\
\text { Hematocrit results } \\
\text { available at entry }\end{array}$ & Not specified & $2,524(22)$ \\
\hline Cote $^{19}$ & 2007 & United States & $\begin{array}{l}\mathrm{FEV}_{1} / \mathrm{FVC}<70 \% \\
\text { Out-patients with a } \\
\text { wide variety of COPD } \\
\text { severity }\end{array}$ & $\begin{array}{l}\text { Illness other than COPD likely to cause } \\
\text { death within } 3 \text { years } \\
\text { Asthma (post-bronchodilator } \mathrm{FEV}_{1} \\
>1.5 \mathrm{~L} \text { ) } \\
\text { Unable to complete lung function tests } \\
\text { and 6-min walk test } \\
\text { Myocardial infarction in past } 3 \text { months } \\
\text { Unstable angina or congestive heart } \\
\text { failure }\end{array}$ & 677 (99) \\
\hline Krishnan $^{16}$ & 2006 & United States & $\begin{array}{l}\text { Mild to moderate } \\
\text { COPD }\end{array}$ & $\begin{array}{l}\text { Missing pulmonary function test (771) } \\
\text { Missing hemoglobin results (100) } \\
\text { Missing health-related quality of life } \\
\text { score (143) } \\
\text { Pulmonary function test results not } \\
\text { acceptable or reproducible (207) } \\
\text { Race other than white or black (35) } \\
\text { Missing information on height, } \\
\text { smoking status, pack-years, or } \\
\text { education (64) }\end{array}$ & $495(18 \%)$ \\
\hline Halpern ${ }^{17}$ & 2006 & United States & $\begin{array}{l}\text { At least } 2 \text { claims with } \\
\text { diagnosis of COPD } \\
\text { from physician/ } \\
\text { supplier or out-patient } \\
\text { file }\end{array}$ & $\begin{array}{l}\text { Under age } 65 \\
\text { Not a United States resident } \\
\text { Known nutritional or hereditary anemia } \\
\text { Disease associated with anemia }\end{array}$ & $\begin{array}{l}132,424 \\
\text { Percentage not specified }\end{array}$ \\
\hline $\mathrm{John}^{18}$ & 2006 & Germany & $\begin{array}{l}\text { Admitted patients on } \\
\text { the Charité Hospital } \\
\text { registry } \\
\text { Lung function tests } \\
\text { Hematology results } \\
\text { obtained within } 10 \\
\text { days before or after } \\
\text { lung function tests }\end{array}$ & $\begin{array}{l}\text { Treated as an out-patient }(11,372) \\
\text { No laboratory results }(5,325) \\
\text { More than one chronic disease }(2,000) \\
\text { Met an exclusion criteria (not specified) } \\
\quad(1,157) \\
\text { Gastrointestinal bleeding, thyroid } \\
\quad \text { disease, blood loss, liver failure, } \\
\text { vitamin B12 or folic acid deficiency }\end{array}$ & $7,337(27)$ \\
\hline John $^{20}$ & 2005 & Germany & COPD diagnosed & $\begin{array}{l}\text { Asthma } \\
\text { Respiratory infection in past } 3 \text { months } \\
\text { Cancer, thyroid/ liver disease, chronic } \\
\text { heart failure, gastrointestinal } \\
\text { hemorrhage, blood loss, } \mathrm{B}_{12} \text { or folic } \\
\text { acid deficiency }\end{array}$ & $\begin{array}{l}101 \\
\text { Percentage not specified }\end{array}$ \\
\hline
\end{tabular}

terized by a normal or low mean corpuscular volume and a low serum or plasma iron concentration in the presence of adequate reticuloendothelial iron stores (normal or increased ferritin level). ${ }^{25,26}$ Typically, the classification anemia of chronic inflammation has also been applied to ane- mia in persons with a high burden of chronic illness without a clearly defined alternative explanation (ie, iron deficiency or renal failure). Indeed, anemia of chronic inflammation may be multifactorial, as it is associated with infection, inflammation, neoplastic disease, acute or chronic immune 


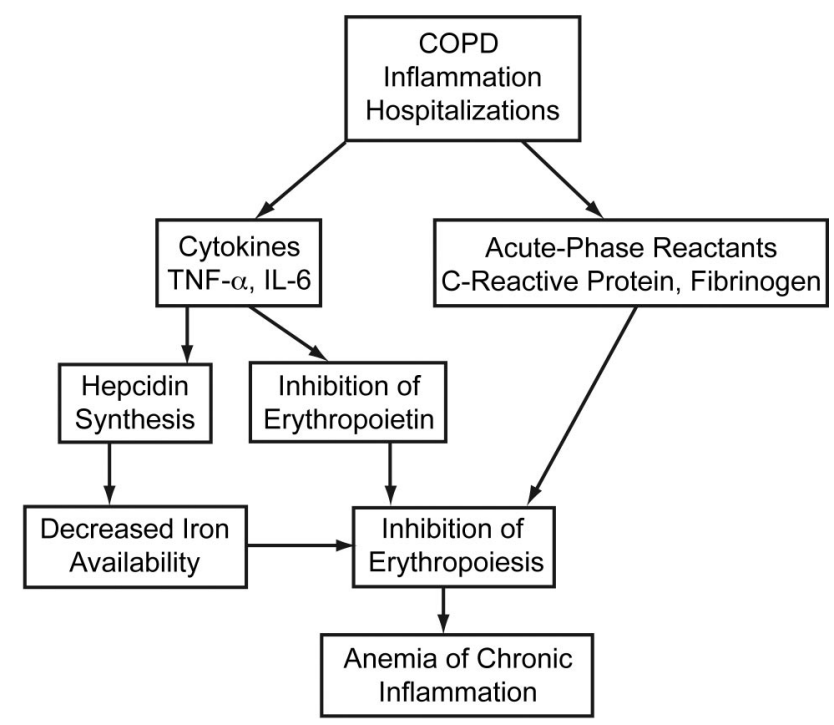

Fig. 2. Possible mechanisms of anemia development in COPD.

activation, and other conditions, including simple tissue injury, surgery, myocardial infarction, heart failure, and diabetes mellitus. 27,28

The mechanism whereby inflammation causes anemia is incompletely established. However, cytokines such as the IL-1, IL-6, and tumor necrosis factor (TNF-alpha), released by activated monocytes in patients with underlying inflammatory conditions, ${ }^{23,29}$ are certainly involved. Several studies have demonstrated that these and other cytokines are associated with the appearance of anemia and may be involved in the pathogenesis by mechanisms such as blunting erythropoietin production in response to hypoxia or decreasing bone marrow responsiveness to erythropoietin. ${ }^{25,30,31}$ Inflammatory cytokines, especially IL-1 $\beta$ and TNF-alpha, may induce apoptosis of red cell precursors as well as down-regulate the appearance of erythropoietin receptors on erythroid progenitor cells. ${ }^{23}$ IL-6 is released by a number of cells in response to infection, trauma, or immunological challenge, and is a major factor in the regulation of the acute inflammatory response. The role of IL-6 in the pathogenesis of anemia first became apparent in the cancer setting, where severe anemia was found to be associated with very high levels of this and other inflammatory cytokines. ${ }^{32}$ It now appears that IL-6 may also profoundly influence iron availability, by directly enhancing hepcidin synthesis within the liver. ${ }^{33-37}$ Also, the IL-6-hepicidin axis is responsible for a dosedependent hypoferremia ${ }^{33}$ and is the key regulator of iron homeostasis in inflammatory states. ${ }^{38-40}$ Thus, hepcidin is the molecular link between inflammation and iron homeostasis and is probably very important in the anemia of inflammation. Its role may actually be broader, in that hepcidin, itself, can suppress erythroid progenitor cell responses to erythropoietin. ${ }^{41}$
The prevalence of anemia in the general population increases with age, ${ }^{42}$ irrespective of COPD or other chronic conditions. For this reason, studies with a predominance of elderly COPD patients need to take this into consideration. ${ }^{9,20}$ Halpern and colleague ${ }^{17}$ excluded COPD patients under the age of 65 in order to limit the impact of younger age as a source of heterogeneity. It is also worth noting that many comorbid conditions are associated with COPD, and those comorbid conditions are more frequent and severe in older patients. ${ }^{11,42}$ Thus, it remains difficult to establish in clinical populations the extent to which COPD itself contributes to the development of anemia.

\section{Morbidity and Mortality}

Anemia can compromise oxygen deliveries to tissues and thus be a cause of dyspnea. ${ }^{43}$ This is likely to contribute to functional limitations and decreased exercise tolerance, especially in those patients who are already oxygen deficient due to diminished lung function. Yet it remains unclear whether correction of anemia favorably influences the clinical course of patients with COPD. In one study, minute ventilation and work of breathing (WOB) were significantly reduced following blood cell transfusion. ${ }^{44} \mathrm{In}$ the 10 patients with COPD the mean minute ventilation decreased from $9.9 \pm 1.0 \mathrm{~L} / \mathrm{min}$ to $8.2 \pm 1.2 \mathrm{~L} / \mathrm{min}$ $(P<.001)$ and WOB decreased from $1.03 \pm 0.24 \mathrm{~J} / \mathrm{L}$ to $0.85 \pm 0.21 \mathrm{~J} / \mathrm{L}(P<.001)$. In control subjects without COPD, hemoglobin was increased to a similar level, but there was no change in ventilation or gas exchange.

Although these findings demonstrate the potential benefit of blood cell transfusion on minute ventilation and WOB, it should be noted that the fall in minute ventilation increased $\mathrm{P}_{\mathrm{aCO}}$ from $38 \mathrm{~mm} \mathrm{Hg}$ to $44 \mathrm{~mm} \mathrm{Hg}$ and a simultaneous fall in $\mathrm{P}_{\mathrm{aO}}$ from $57 \mathrm{~mm} \mathrm{Hg}$ to $53 \mathrm{~mm} \mathrm{Hg}$ finding comparable to the inverse correlation between hematocrit and $\mathrm{P}_{\mathrm{aCO}_{2}}$ demonstrated by Chambellan and colleagues. ${ }^{9}$ Consequently, the overall effectiveness of this corrective therapeutic intervention should be interpreted with caution. The advantages of increasing the hemoglobin level may be countered by the potentially severe consequences of negatively altering blood gases. However, Chambellan and colleagues ${ }^{9}$ found that each $5 \%$ increase in hematocrit was associated with improved survival, which suggests that hematocrit is a strong prognostic predictor of mortality. Frequent hospitalizations and duration of stay were also inversely correlated with higher hematocrit. Caution is also required with the age of transfused red blood cell. Older cells are most likely to become stiffer and to be unable to penetrate the tissue microcirculation, so these transfusions may provide useful volume expansion but may not increase oxygen delivery. Further research is warranted 
into the effects of blood transfusion as a remedial intervention in anemic COPD patients.

Two studies ${ }^{45,46}$ in which anemic COPD patients had undergone surgery found that mortality was higher than in the non-COPD subgroups. A recent study found that a low preoperative hematocrit was also a predictor of a poor postoperative outcome. ${ }^{46}$ These observations may suggest that COPD patients are more sensitive to the effects of anemia, acute or chronic, by the preexisting tissue hypoxia. Nevertheless, it may be argued that the higher mortality was the result of greater blood loss during surgery, especially as both studies had patients who underwent surgery for upper-gastrointestinal bleeding ${ }^{45}$ or abdominal aortic aneurysm. ${ }^{45}$ Conversely, in the BODE study ${ }^{47}$ a lower hematocrit was significantly associated with COPD mortality. However, the populations of COPD patients in the studies by Chambellan and colleagues ${ }^{9}$ and Celli and colleagues ${ }^{47}$ were very different. In the Chambellan study the patients were on long-term oxygen therapy for severe COPD, whereas the patients in the Celli study had various levels of respiratory impairment.

Halpern and colleagues ${ }^{17}$ found that COPD patients with anemia had a nearly 2-fold higher death rate (262 per 1,000 person-years of follow-up) than non-anemic patients (133 per 1,000 person-years of follow-up, $P<.001$ ). Although that study included 132,424 COPD patients, it was a retrospective analysis of administrative claims data, so only patients who had Medicare claims with appropriate ICD-9 diagnosis codes were identified, and the presence of those codes is not a guarantee of correct diagnoses. Although the sample size was large, relying on the ICD-9 codes, as opposed to threshold hemoglobin values as advocated by the World Health Organization, would suggest that the observed prevalence and consequences of anemia in that cohort was underestimated and unaccounted.

Cote and colleagues ${ }^{19}$ reported that $53(47 \%)$ anemic COPD patients and 187 (31\%) non-anemic COPD patients died during the study $(P=.01)$, and that estimate would include a greater detrimental consequence of anemia on the likelihood of mortality. However, other factors such as age, comorbidities, and BODE score differed significantly between survivors and non-survivors $(P<.001)$, once again highlighting the difficulty of attributing causality in an observed study.

\section{Quality of Life}

Health-related quality of life is an important clinical outcome for individuals with advanced air-flow limitation and for their healthcare providers. This clinical measure helps to differentiate between people with different severities of lung disease and permits the evaluation of the impact of a specific intervention on patients' lives. ${ }^{48}$ Theander and Unosson ${ }^{49}$ showed that in COPD patients fa- tigue is a common symptom: nearly half of the patients reported daily fatigue, and fatigue was negatively associated with physical function, cognition, psychosocial wellbeing, and health-related quality of life. Dyspnea and fatigue are also well known manifestations of anemia, ${ }^{50}$ so it is logical to assume that patients with COPD and anemia may have substantially worse dyspnea and fatigue. Krishnan and colleagues ${ }^{16}$ performed a post-hoc analysis of a study that enrolled participants from a general population in New York city. Of the 495 (18\%) patients with moderate to severe COPD, 37 (8\%) had anemia. Although the prevalence of anemia was lower in the cohort of COPD patients, in COPD patients with anemia the analysis showed significantly lower physical functioning scores $(P=.002)$ and physical component summary scores $(P=.02)$, but not mental component summary scores with the Medical Outcomes Study 36-item short-form questionnaire (SF36), which measures health-related quality of life. ${ }^{16}$ This may indicate that the presence of anemia in COPD patients negatively affects only the physical, and not the mental, aspect of daily life. The SF-36 has been supported as a valid instrument for quantifying health-related quality of life, ${ }^{16}$ but there are other disease-specific health-related quality of life questionnaires for individuals with COPD. ${ }^{51,52}$ It could be argued that a combination of the available questionnaires may have generated more reliable results.

\section{Summary and Comments}

The findings of this review indicate the prevalence of comorbid anemia in COPD patients to be $7.5 \%-34 \%$. Most of the studies have reported deleterious effects from comorbid anemia in patients with COPD, on quality of life, mortality, and healthcare utilization. The true prevalence of anemia in patients with COPD is unknown. There is lack of consensus agreement regarding this hematological abnormality's true frequency. Therefore, based on the findings from the existing literature, it indicates that more work is necessary to establish the true prevalence of anemia in COPD. Additionally, the pathophysiological mechanisms involve the potential association between anemia and disease severity; the clinical impact of anemia in COPD, and, ultimately, the therapeutic effects of raising the hemoglobin concentration on physiological and clinical variables are worthy of future enquiry. Additional studies aimed at psychological wellbeing (eg, anxiety and depression) in COPD patients with comorbid anemia are likely to be informative. Another caveat that is worthy of consideration is that COPD patients are more likely to be hospitalized because of exacerbations, and hospitalized patients will probably exhibit more anemia than that in a general population. Though a few studies have identified associations between anemia and COPD, many of those studies 


\section{Anemia in COPD: A Systematic Review}

have been retrospective and had various methodological limitations. We were unable to examine the methodological qualities of the studies. Therefore, robust and prospective studies are needed in well characterized COPD patients to determine the true prevalence and consequences of concomitant anemia. Furthermore, the study design should include longitudinal assessment of lung function and hemoglobin, to account for any changes during exacerbation-free periods in patients with COPD, and to establish the influence of anemia on the natural history of COPD.

\section{REFERENCES}

1. Pauwels RA, Buist AS, Calverley PM, Jenkins CR, Hurd SS. Global strategy for the diagnosis, management, and prevention of chronic obstructive pulmonary disease. NHLBI/WHO Global Initiative for Chronic Obstructive Lung Disease (GOLD) Workshop summary. Am J Respir Crit Care Med 2001;163(5):1256-1276.

2. Mannino DM, Buist AS. Global burden of COPD: risk factors, prevalence, and future trends. Lancet 2007;370(9589):765-773.

3. Viegi G, Pistelli F, Sherrill DL, Maio S, Baldacci S, Carrozzi L. Definition, epidemiology and natural history of COPD. Eur Respir J 2007;30(5):993-1013.

4. Murray CJ, Lopez AD. Alternative projections of mortality and disability by cause 1990-2020: Global Burden of Disease Study. Lancet 1997;349(9064):1498-1504.

5. Niederlander E. Cause of death in the EU. Statistics in focus - population and social conditions. Eurostat (European Communities) 2005; 101:1-12.

6. Celli BR, Cote CG, Lareau SC, Meek PM. Predictors of Survival in COPD: more than just the $\mathrm{FEV}_{1}$. Respir Med 2008;102(Suppl 1): S27-S35.

7. Barr RG, Celli BR, Mannino DM, et al. Comorbidities, patient knowledge, and disease management in a national sample of patients with COPD. Am J Med 2009;122(4):348-355.

8. U.S. Department of Health and Human Services. National Institutes of Health National Heart Lung and Blood Institute. Morbidity and Mortality: 2009 Chart book on Cardiovascular, Lung and Blood Diseases.

9. Chambellan A, Chailleux E, Similowski T; ANTADIR Observatory Group. Prognostic value of the hematocrit in patients with severe COPD receiving long-term oxygen therapy. Chest 2005;128(3):12011208.

10. Barnes PJ, Celli BR. Systemic manifestations and comorbidities of COPD. Eur Respir J 2009;33(5):1165-1185.

11. Rennard SI. Inflammation in COPD: a link to systemic comorbidities. Eur Respir Rev 2007;16(105):91-97.

12. Yohannes AM, Baldwin RC, Connolly MJ. Depression and anxiety in elderly patients with chronic obstructive pulmonary disease. Age Ageing 2006;35(5):457-459.

13. Similowski T, Agusti A, MacNee W, Schonhofer B. The potential impact of Anemia of chronic disease in COPD. Eur Respir J 2006; 27(2):390-396.

14. Nutritional anemias. Report of a WHO Scientific Group. WHO Tech Rep Sr 1968;405(1):5-37.

15. Izaks GJ, Westednorop RGJ, Knook DL. The definition of Anemia in older persons. JAMA 1999;281(18):1714-1717.

16. Krishnan G, Grant BJ, Muti PC, et al. Association between anemia and quality of life in a population sample of individuals with chronic obstructive pulmonary disease. BMC Pulm Med 2006;6:23.

17. Halpern MT, Zilberberg MD, Schmier JK, Lau EC, Shorr AF. Anemia, costs and mortality in chronic obstructive pulmonary disease. Cost Eff Resour Alloc 2006;4:17.
18. John M, Lange A, Hoernig S, Witt C, Anker SD. Prevalence of anemia in chronic obstructive pulmonary disease: comparison to other chronic diseases. Int J Cardiol 2006;111(3):365-370.

19. Cote C, Zilberberg MD, Mody SH, Dordelly LJ, Celli B. Haemoglobin level and its clinical impact in a cohort of patients with COPD. Eur Respir J 2007;29(5):923-929.

20. John M, Hoernig S, Doehner W, Okonko DD, Witt C, Anker SD. Anemia and inflammation in COPD. Chest 2005;127(3):825-829.

21. Shorr AF, Doyle J, Stern L, Dolgitser M, Zilberberg MD. Anemia in chronic obstructive pulmonary disease: epidemiology and economic implications. Curr Med Res Opin 2008;24(4):1123-1130.

22. Weiss G, Goodnough LT. Anemia of chronic disease. N Engl J Med 2005;352(10):1011-1023.

23. Tassiopoulos S, Kontos A, Konstantopoulos K, et al. Erythropoietic response to hypoxaemia in diffuse idiopathic pulmonary fibrosis, as opposed to chronic obstructive pulmonary disease. Respir Med 2001; 95(6):471-475.

24. Means RT Jr, Krantz SB. Progress in understanding the pathogenesis of the anemia of chronic disease. Blood 1992;80(7):1639-1647.

25. Cartwright GE. The anemia of chronic disorders. Semin Hematol 1966;3(4):351-375.

26. Cash JM, Sears DA. The anemia of chronic disease: spectrum of associated diseases in a series of unselected hospitalized patients. Am J Med 1989;87(6):638-644.

27. Opasich C, Cazzola M, Scelsi L, De Feo S, Bosimini E, Lagiolia R, et al. Blunted erythropoietin production and defective iron supply for erythropoiesis as major causes of anemia in patients with chronic heart failure. Eur Heart J 2005;26(21):2232-2237.

28. Moldawer LL, Gelin J, Schersten T, Lundholm KG. Circulating interleukin 1 and tumor necrosis factor during inflammation. Am J Physiol 1987, 253(6 Pt 2):R922-R928.

29. Means RT, Jr., Krantz SB. Inhibition of human erythroid colonyforming units by interferons alpha and beta: differing mechanisms despite shared receptor. Exp Hematol 1996;24(2):204-208.

30. Means RT, Jr., Dessypris EN, Krantz SB. Inhibition of human erythroid colony-forming units by interleukin-1 is mediated by gamma interferon. J Cell Physiol 1992;150(1):59-64.

31. Maccio A, Madeddu C, Massa D, et al. Hemoglobin levels correlate with interleukin-6 levels in patients with advanced untreated epithelial ovarian cancer: role of inflammation in cancer-related anemia. Blood 2005;106(1):362-367.

32. Nemeth E, Rivera S, Gabayan V, et al. IL-6 mediates hypoferremia of inflammation by inducing the synthesis of the iron regulatory hormone hepcidin. J Clin Invest 2004;113(9):1271-1276.

33. Nemeth E, Tuttle MS, Powelson J, et al. Hepcidin regulates cellular iron efflux by binding to ferroportin and inducing its internalization. Science 2004;306(5704):2090-2093.

34. Raj DS. Role of interleukin-6 in the anemia of chronic disease. Semin Arthritis Rheum 2009;38(5):382-388.

35. Ganz T. Hepcidin in iron metabolism. Curr Opin Hematol 2004; 11(4):251-254.

36. Ganz T, Nemeth E. Iron imports. IV. Hepcidin and regulation of body iron metabolism. Am J Physiol Gastrointest Liver Physiol 2006; 290(2):G199-G203.

37. Rivera S, Nemeth E, Gabayan V, Lopez MA, Farshidi D, Ganz T. Synthetic hepcidin causes rapid dose-dependent hypoferremia and is concentrated in ferroportin-containing organs. Blood 2005;106(6): 2196-2199.

38. Roy CN, Andrews NC. Anemia of inflammation: the hepcidin link. Curr Opin Hematol 2005;12(2):107-111.

39. Andrews NC. Anemia of inflammation: the cytokine-hepcidin link. J Clin Invest 2004;113(9):1251-1253. 


\section{Anemia in COPD: A Systematic Review}

40. Dallalio G, Law E, Means RT, Jr. Hepcidin inhibits in vitro erythroid colony formation at reduced erythropoietin concentrations. Blood 2006;107(7):2702-2704.

41. Guralnik JM, Eisenstaedt RS, Ferrucci L, Klein HG, Woodman RC. Prevalence of anemia in persons 65 years and older in the United States: evidence for a high rate of unexplained anemia. Blood 2004; 104(8):2263-2268.

42. Carroz KP. [Anemia in COPD: should it be taken into consideration?]. Arch Bronconeumol 2007;43(7):392-398. Article in Spanish.

43. Fabbri LM, Rabe KF. From COPD to chronic systemic inflammatory syndrome? Lancet 2007;370(9589):797-799.

44. Schonhofer B, Wenzel M, Geibel M, Kohler D. Blood transfusion and lung function in chronically anaemic patients with severe chronic obstructive pulmonary disease. Crit Care Med 1998;26(11):1824-1828.

45. Cappell MS, Nadler SC. Increased mortality of acute upper gastrointestinal bleeding in patients with chronic obstructive pulmonary disease. A case controlled, multiyear study of 53 consecutive patients. Dig Dis Sci 1995;40(2):256-262.

46. Upchurch GR, Jr., Proctor MC, Henke PK, et al. Predictors of severe morbidity and death after elective abdominal aortic aneurysmectomy in patients with chronic obstructive pulmonary disease. J Vasc Surg 2003;37(3):594-599.

47. Celli BR, Cote CG, Marin JM, Casanova C, Montes de Oca M, Mendez RA, et al. The body-mass index, airflow obstruction, dyspnea, and exercise capacity index in chronic obstructive pulmonary disease. N Engl J Med 2004;350(10):1005-1012.

48. Mahler DA, Jones PW. Measurement of dyspnea and quality of life in advanced lung disease. Clin Chest Med 1997;18(3):457-469.

49. Theander K, Unosson M. Fatigue in patients with chronic obstructive pulmonary disease. J Adv Nurs 2004;45(2):172-177.

50. Sobrero A, Puglisi F, Guglielmi A, Belvedere O, Aprile G, Ramello M, Grossi F. Fatigue: a main component of anemia symptomatology. Semin Oncol 2001;28(2 Suppl 8):15-18.

51. Jones PW, Quirk FH, Baveystock CM. The St George's Respiratory Questionnaire. Respir Med 1991;85(Suppl B):25-31; discussion 3337.

52. Schünemann HJ, Goldstein R, Mador MJ, McKim D, Stahl E, Puhan M, et al. A randomised trial to evaluate the self-administered standardised chronic respiratory questionnaire. Eur Respir J 2005;25(1):31-40. 